IRENA KAMIŃSKA-SZMAJ

ORCID: 0000-0003-0367-3799

Instytut Filologii Polskiej, Wydział Filologiczny

Uniwersytet Wrocławski

\title{
Sterowanie pamięcią zbiorową. Propagandowy wielogłos o wojnie polsko-sowieckiej/radzieckiej (1919-1921)
}

\begin{abstract}
Abstrakt
$\mathrm{W}$ artykule przedstawiono kreowanie - $\mathrm{w}$ trzech kolejnych okresach historycznych — obrazu wojny z lat 1919-1921 między Rzeczpospolitą Polską (II RP) a Rosyjską Federacyjną Socjalistyczną Republiką Radziecką (RF SRR), która jest nazywana: wojną polsko-sowiecką, wojną polsko-bolszewicką, wojną polsko-rosyjską, wojną polsko-radziecką, wojną 1920. Nazwa, opis i ocena tej wojny, zarówno w II RP, w PRL, jak i współcześnie, jest zależna od propagandowych celów, bieżącej polityki i nastawienia do sąsiada ze Wschodu. Obraz wojny z lat 1919-1921 jest silnie zideologizowany, o czym świadczy leksyka i metaforyka wykorzystywana do pobudzania emocji, do silnego wartościowania wroga, a tym samym do sterowania zachowaniami społeczeństwa i tworzenia mitów, stereotypów, które na długo przechowywane są w pamięci zbiorowej. Historia tego konfliktu zbrojnego była i jest pisana pod presją różnych ideologii i strategii propagandowych.

Celem artykułu jest wykazanie, że obraz wojen w przekazach werbalnych (podręcznikach do nauki historii, monografiach historycznych, dziełach literackich, historiach mówionych etc.) i wizualnych (malarskich, filmowych etc.) zależy od kontekstu historycznego, uwarunkowań społeczno-politycznych oraz punktu widzenia podmiotu budującego narrację o danym wydarzeniu. Kształtowaniu pamięci zbiorowej zawsze towarzyszy wartościowanie, selekcja wydarzeń i różnorodne silne emocje.
\end{abstract}

Słowa kluczowe: wojna polsko-sowiecka, sterowanie pamięcią zbiorową, ideologizacja historii.

Każda władza, a zwłaszcza autorytarna, stara się wykorzystywać pamięć historyczną do własnych celów propagandowych. Rządzący z tradycji i historii czerpią przede wszystkim to, co jest przydatne w osiąganiu doraźnych zamierzeń politycznych, co można podporządkować głoszonej przez nich ideologii i co może służyć legitymizacji ich władzy. Wzmacniają więc znaczenie pewnych historycznych faktów, mitologizują je, włączając do kanonu pamięci zbiorowej poprzez rytualizację 
rocznicowych obchodów, organizowanie rekonstrukcji wybranych bitew, apeli poległych, budowanie pomników ku czci, nazywanie ulic i placów, nagradzanie orderami, budowanie muzeów, inspirowanie twórczości literackiej, filmowej etc. Instrumentów do kształtowania polityki historycznej jest niezwykle dużo, a ich zasób zwiększa się wraz z rozwojem technologii przetwarzania i prezentowania informacji (na przykład strony internetowe, gry historyczne online, gry multimedialne). Dla sterników świadomości zbiorowej ważne jest kreowanie - zgodne z upowszechnianą przez nich wizją przeszłości i przyszłości, a także z deklarowanym systemem wartości - nowych bohaterów, często przez wydobywanie ich z zapomnianych lub zmanipulowanych przekazów historycznych (współcześnie na przykład tworzenie kultu „żołnierzy wyklętych”), zastępując ich tymi, których należy potępić i pogrążyć w niebycie (na przykład współcześnie lewicowych działaczy, komunistycznych bohaterów II wojny światowej, nieakceptowanych twórców II lub III RP). Toteż hiperbolizacji ważności wybranych zdarzeń i bohaterów historycznych towarzyszy marginalizacja lub zacieranie pamięci o innych faktach i ludziach z przeszłości. Rządzący bowiem zdają sobie sprawę z tego, że pamięć przeszłości wpływa na percepcję aktualnych zdarzeń, buduje zaprogramowaną przez nich tożsamość narodową (klasową, wspólnotową). Polityka historyczna bywa bardzo groźnym narzędziem manipulowania świadomością zbiorową, zwłaszcza gdy w doraźnych celach propagandowych władza stara się zarządzać badaniami naukowymi, narzucać swoją wizję twórczości kulturalnej i wkraczać na teren edukacji i wychowania (na przykład „nowego człowieka”, „prawdziwego patrioty”). Aksjologizacja wydarzeń historycznych widoczna jest nie tylko w ich selekcji i uprawomocnianiu w dyskursie publicznym, lecz także w doborze środków językowych opisujących fakty z przeszłości lub dokumentujących dziejącą się „na żywo” historię. W każdym języku władzy, niezależnie od ustroju, toczy się walka o podporządkowaną dominującej ideologii pamięć przeszłości, której towarzyszy walka o nowe mity, symbole i wzorce osobowe. W parze z kształtowaniem pamięci zbiorowej zawsze idzie wartościowanie, selekcja wydarzeń i różnorodne silne emocje (zob. szerzej między innymi Kula 2004, Szacka 2006, Kwiatkowski 2008).

Ideologizuje się też, podporządkowując celom propagandowym, różne konflikty zbrojne, w których „nasi” - niezależnie od faktów historycznych — zawsze walczyli o słuszną sprawę lub musieli się bronić, byli ofiarami, a „oni” to wrogowie „naszych” interesów lub bezwzględni agresorzy. W konfliktach zbrojnych - niezależnie od przyczyn i skutków - racja leży po „naszej” stronie, lecz można też usprawiedliwiać działania najeźdźcy, przyjmując prymat ideologii, na przykład klasowej. Obraz wojen w przekazach werbalnych (podręcznikach do nauki historii, monografiach historycznych, dziełach literackich, historiach mówionych etc.) i wizualnych (malarskich, filmowych etc.) zawsze zależy od uwarunkowań społeczno-politycznych oraz punktu widzenia podmiotu budującego narrację o danym wydarzeniu.

W artykule tym pokażę kreowanie - w trzech kolejnych okresach historycznych - obrazu wojny z lat 1919-1921 między Rzeczpospolitą Polską (II RP) a Rosyj- 
ską Federacyjną Socjalistyczną Republiką Radziecką (RF SRR), która jest nazywana: wojna polsko-sowiecka, wojna polsko-bolszewicka, wojna polsko-rosyjska, wojna polsko-radziecką, wojna 1920. Nazwa, opis i ocena tej wojny, zarówno w II RP, w PRL, jak i współcześnie, jest zależna od propagandowych celów, bieżącej polityki i nastawienia do sąsiada ze Wschodu, z którym ta wojna była prowadzona. Obraz wojny z lat 1919-1921 jest bardzo zideologizowany, o czym świadczy leksyka i metaforyka wykorzystywana do pobudzania emocji, do silnego wartościowania wroga, a tym samym do sterowania zachowaniami społeczeństwa i tworzenia mitów, stereotypów, które na długo przechowywane są w pamięci zbiorowej. Historia tego konfliktu zbrojnego była i jest pisana pod presją różnych ideologii i strategii propagandowych.

\section{Obraz wojny 1919-1921 w II RP}

Po zakończeniu I wojny światowej i ukonstytuowaniu się rządu II RP oraz przeprowadzeniu w styczniu 1919 roku wyborów do Sejmu problem granic Rzeczypospolitej Polskiej pozostawał ciągle otwarty. Naczelnik Państwa — Józef Piłsudski - przystąpił do realizowania swojej idei federacyjnej. W połowie lutego 1919 roku „padły pierwsze strzały w niewypowiedzianej wojnie pomiędzy Polską a Rosją Radziecką" (Garlicki 1989: 52). Jan Dąbski - przewodniczący polskiej delegacji pokojowej w Rydze - opisując kalendarium wydarzeń z lat 1919-1921, wyraźnie stwierdził, że „wojna pomiędzy Rzecząpospolitą Polską a Rosyjską Republiką Rad nie została nigdy w sposób formalny wypowiedziana”, lecz — dodaje - „odpowiedzialność za wybuch tej wojny zwala oczywiście rząd sowiecki na rząd polski” (Dąbski 1931: 7). Wojna trwała do października 1920 roku, a spór o granice zakończył podpisany 18 marca 1921 roku w Rydze traktat pokojowy przyznający Polsce zachodnią część ziem Ukrainy i Białorusi oraz potwierdzający wcześniej ustaloną polsko-litewską linię demarkacyjną na zachód od Wilna.

\subsection{Prasowe komentarze „na gorąco” o działaniach wojennych}

Pierwsze wiadomości w prasie o wojnie na Wschodzie były dość lakoniczne i podawane głównie były w formie sprawozdawczej. Opinię publiczną interesowały przede wszystkim sprawy wewnętrzne, kampania wyborcza, spór o konstytucję, reformy przeprowadzane przez rząd, a przede wszystkim powojenne trudy dnia codziennego. Dopiero zajęcie Kijowa (7 maja 1920 roku) i tryumfalny powrót z frontu ukraińskiego Piłsudskiego do Warszawy ożywiły ton propagandowy publikacji prasowych. Naczelnik Państwa był przez tłumy mieszkańców Warszawy witany jak bohater, a na specjalnie powołanym posiedzeniu Sejmu marszałek Trąmpczyński, używając podniosłego słownictwa, witał wodza „wracającego ze szlaku Bolesława Chrobrego" 
(Garlicki 1989: 59; Pobóg-Malinowski 1956: 257). Prasa (oprócz komunistycznej) wykorzystała „victorię kijowską” do wzmocnienia pozytywnych nastrojów społeczeństwa zmęczonego trudami wojny i chaosem powojennym, a także do wyzwolenia siły i poczucia wartości narodu polskiego poniżanego przez lata zaborów. Zainteresowanie wojną osiągnęło apogeum wraz ze zbliżaniem się wojsk rosyjskich do Warszawy. Bojowy nastrój mieszkańców Warszawy tak opisuje w swoim Dzienniku 14 sierpnia 1920 roku Maria Dąbrowska:

Rosja zebrała przeciw nam wszystkie siły. Front nasz zaczął się uginać i łamać [...] naród pod wpływem klęski obudził się nareszcie. [...] Ulice Warszawy rozbrzmiewają marszem ochotników, głosem trąbek, każdego przechodnia obowiązują teraz trzy znaki: białego krzyża, czerwonego krzyża i pożyczki państwowej. (Dąbrowska 1988: 150)

\subsubsection{Obrona „przedmurza Chrześcijaństwa”}

Ideologizacja obrazu wojny z Rosją sowiecką przez prasę prawicową i prorządową była ściśle związana z przypisywaniem Polsce misji ratowania cywilizacji zachodniej przed nawała bolszewicką. Przyjmując taki punkt widzenia, w artykułach prasowych na pierwszy plan wysuwano kreowany przez siebie niezwykle negatywny obraz sąsiada ze Wschodu (nazywanego: Bolszewja, Sowdepja, Rosja bolszewicka, Rosja sowiecka). Ważniejsze od doniesień wojennych, relacji z przebiegu frontu wschodniego, refleksji nad przyczynami i skutkami wojny stawały się obrazy okrutnego bolszewika i wzniecanie strachu przed bolszewizmem, który szatańska wstęga czerwona okrąża ziemię cała. Przestrzegano w prasie, że widmo bolszewizmu krąży nad Polską, a kreślony obraz porewolucyjnej Rosji napawał grozą i przerażeniem (szerzej zob. Kamińska-Szmaj 1994). W tygodniku ludowców opisywano „Jak bolszewicy hulają na zajętych ziemiach polskich” (nagłówek, „Piast” 15 sierpnia 1920 roku), a w prawicowej "Gazecie Warszawskiej” przekonywano, że „za ścianą wschodnią” szerzy się „głód, nędza, zniszczenie”. Gdy latem 1920 roku Armia Czerwona przekroczyła Bug, w prasie zaczęły pojawiać się artykuły wzywające do obrony „przed nawałą bolszewicką", przed „zarazą, która z potężnej Rosji zrobiła piekło na ziemi” („Piast” 8 sierpnia 1920 roku). W opublikowanym w 1921 roku przez Prezydium Ligi Antybolszewickiej Memoriale nr 2. Do wysokiego Sejmu, Rzadu i Społeczeństwa Rzeczypospolitej Polskiej w sprawie zwalczania bolszewizmu w Polsce podkreślano, że „walcząc z bolszewizmem Polacy idą torami zgodnymi ze swą wielką tradycją i wzniosłem posłannictwem bronienia przedmurza Chrześcijaństwa”. Nawet ci politycy, którzy krytycznie oceniali federacyjną politykę Józefa Piłsudskiego i działania wojenne na kresach wschodnich, ulegli ideologicznej narracji o „wojnie z bolszewizmem" i konieczności obrony Europy Zachodniej przed rewolucją i komunizmem. Bitwa Warszawska (13-25 sierpnia 1920 roku) obrosła w legendę - pisano o niej, że był to "Cud nad Wisłą" (modyfikacja tytułu artykułu Stanisława Strońskiego O cud Wisty, „Rzeczpospolita” 14 sierpnia 1920 roku). Prasa prawicowa przekonywała, że 
ten cud ziścił się wskutek nabożeństw i modłów oraz dzięki zdolnościom militarnym gen. Józefa Hallera. Z kolei zwolennicy Piłsudskiego przypisywali wszelkie zasługi w walce z Rosją czerwona Naczelnikowi Państwa, który powstrzymał czerwony najazd, uratował Polskę i Europę przed czerwona niewola, czerwonym jarzmem Moskwy.

\subsubsection{Dwugłos lewicy o wojnie polsko-sowieckiej}

Zainteresowanie polskiej lewicy działaniami wojennymi na Wschodzie wzmogło się wraz kontrofensywą Armii Czerwonej latem 1920 roku i przesuwaniem się jej w głąb kraju, zbliżaniem się do Warszawy. Lewica oceniała wojnę polsko-rosyjską z dwóch perspektyw. Socjaliści widzieli w niej zagrożenie dla niepodległości Rzeczypospolitej, komuniści zaś łączyli z nią nadzieję na zaprowadzenie ładu bolszewickiego w Polsce, ustanowienie dyktatury proletariatu i rozprzestrzenienie się rewolucji na zachód Europy. Retoryka obu przeciwstawnych lewicowych ugrupowań świadczy o odmienności ich dążeń i wizji losów kraju nad Wisła.

Komuniści widzieli w Armii Sowieckiej „rycerzy wyzwolenia całego ludu pracującego z pęt kapitału” i wznosili hasła: „Niech żyje Polska Republika Rad!” (Odezwa Warszawskiej Rady Delegatów Żotnierskich, lipiec 1920, zob. KPP w obronie... 1952: 51). W czerwcu 1920 roku komuniści polscy protestowali przeciwko wojnie polsko-sowieckiej, czyli przeciwko „kontrrewolucji imperialistycznej i napaściom burżuazji na Rosję Sowiecką", rozpowszechniając wśród żołnierzy odezwę przestrzegającą: „Kto z Rosją Sowiecką walczy, ten walczy z klasą robotniczą świata całego, ten jest wrogiem ludu!" (KPP w obronie... 1952: 57). Podjęli też działania na zapleczu frontu (między innymi Feliks Dzierżyński, Feliks Kon, Julian Marchlewski), tworząc Tymczasowy Komitet Rewolucyjny Polski (Polrewkom) i wydając Manifest, w którym zapowiadali, że będą „kłaść podwaliny pod przyszły ustrój Sowiecki Polskiej Socjalistycznej Republiki Rad”. W wydawanym przez siebie w Białymstoku organie prasowym „Goniec Czerwony” w pierwszym numerze (7 sierpnia 1920 roku) na pierwszej stronie dużą pogrubioną czcionką zamieszczono hasła: Niech żyje Polska Socjalistyczna Respublika Rad! Niech żyje bohaterska Armia Czerwona!. Dla komunistów Piłsudski, który wszczą wojnę przeciw rewolucji proletariackiej, to zaprzaniec, zdrajca socjalizmu, żandarm kapitalizmu, dlatego robotnik polski nie powinien pomagać armii kontrrewolucjonistów polskich, lecz armii czerwonej.

Socjaliści w artykułach zamieszczanych w „Robotniku” w latach 1918-1919 wyraźnie podkreślali swój negatywny stosunek do rewolucji bolszewickiej, odżegnując się od metod zdobywania władzy gwałtem i przemocą. Wyjaśniali, że „socjalna demokracja nic nie ma wspólnego z bolszewicką teorią i bolszewicką praktyką" (23 marca 1919 roku). Pod koniec 1919 roku w „Robotniku” pojawiło się wiele artykułów przeciwko wojnie na Wschodzie, w których potępiano wojnę, ponieważ „wojna to dolewanie oliwy do bolszewickiego ognia” (2 października 1919 roku). Jednak w obliczu niebezpieczeństwa grożącego Polsce, gdy Armia Czerwona prze- 
kroczyła Bug, socjaliści wzywali w odezwie skierowanej do robotników: Do broni! Ratujmy Ojczyznę! Pamiętajmy dobrze o naszym przyszłym losie!. W tej odezwie, przedrukowanej w „Robotniku” (8 sierpnia 1920 roku), przekonywano, że rząd Rosji sowieckiej dąży do „zupełnego stratowania, zniszczenia Polski Niepodległej”, a bolszewicy „niosą nam niewolę, zniszczenie, wygłodzenie kraju, nędzę i poniżenie robotnika polskiego”. W pepesowskim „Robotniku” drukowano Wskazania dla towarzyszy w miejscowościach zajętych przez bolszewików (7 sierpnia 1920 roku), a bolszewików nazywano „hordami, które za pomocą gwałtu, rabunku i pożogi wprowadzać zaczęły na ziemiach polskich rosyjski komunizm” (1 września 1920 roku). W czasie wojny, gdy na teren Polski wkroczył żołnierz sowiecki, narodził się niezwykle negatywny stereotyp bolszewika, upowszechniany w prasie (oprócz komunistycznej), w różnych ulotkach, broszurach i wydawnictwach książkowych (zob. Kamińska-Szmaj 1994: 132-167).

Stosunek lewicy do wojny polsko-sowieckiej i do bolszewików niezwykle wyraźnie i jednoznacznie uwypuklił różnice ideologiczne między socjalistami a komunistami polskimi. Ci pierwsi domagali się zmiany ustroju bez terroru i bez bagnetów rosyjskich, a niepodległa, wolna ojczyzna była dla nich wartością najwyższą, komuniści zaś łączyli losy Polski ze Związkiem Sowieckim — jedyna ojczyzną proletariatu całego świata.

\subsection{Obraz wojny z bolszewikami w podręcznikach szkolnych II RP}

Szkolna edukacja historyczna odgrywa ważną rolę w kształtowaniu świadomości społecznej, toteż obóz rządzący w II RP, zwłaszcza po przewrocie majowym w 1926 roku, konsekwentnie - poprzez naukę historii - wprowadzał swoje ideały wychowawcze. W podręcznikach wojnę polsko-sowiecką przedstawiano jako konieczność, jako heroiczne działanie obronne przed „zalewem bolszewickim” i jako „wielkie zwycięstwo". Tytuły tematów w programach nauczania (na przykład „Odparcie najazdu na Polskę w 1920 roku”, „Obrona Polski w 1920 roku”) nie pozostawiały wątpliwości, kto był najeźdźcą, przed którym trzeba było się bronić. Z kolei tytuły podrozdziałów w podręcznikach zawierały jednoznaczną ocenę wroga przez użycie słownictwa zabarwionego negatywnie, na przykład „Groza bolszewicka”, „Najazd armii bolszewickiej”, lub pozytywnie przez odwołanie do uczuć religijnych, na przykład „Cud nad Wisłą” (szerzej zob. Składanowski 2004).

W jednym z podręczników do nauki historii dla VI klasy szkoły powszechnej rozdział pod tytułem „Zmartwychwstanie” kończy się krótką informacją o wojnie z bolszewikami, „którzy w lecie 1920 podeszli nawet pod samą Warszawę, gdzie ponieśli zupełną klęskę”, a potem „musieli zawrzeć w Rydze pokój, ustalający granice Polski poprzez Białą Ruś i Wołyń do rzeki Zbrucz" (Jarosz 1933: 204). Bardziej emocjonalny przekaz o tej wojnie zawarty jest w podręczniku dla klas VI Janiny Schönbrenner, który zaczyna się od słów: „Bolszewicy rozpoczęli wojnę z Polską; 
chcieli oni narzucić Polsce a potem innym państwom europejskim swój sposób rządzenia" (Schönbrenner 1937: 108). Autorka podkreśla zasługi Józefa Piłsudskiego i zwycięskiej armii polskiej oraz ofiarność społeczeństwa w chwili grozy, gdy wojska bolszewickie podeszły pod sama stolicę. W podręcznikach historii Piłsudski był przedstawiany jako bohater, który ocalił Polskę i cała Europe przed pożoga bolszewi$c k a$, a sama wojna została uznana za jedno z najważniejszych w dziejach Polski zwycięstw militarnych, które można porównać „z pogromem Turków pod Wiedniem przez Sobieskiego" (cyt. za: Składanowski 2004: 61).

\section{Propagandowe obrazy wojny polsko-radzieckiej w PRL}

W czasach PRL jednym z głównych celów propagandowych było potępienie burżuazyjnych rządów II Rzeczypospolitej, wyzyskujących chłopów i robotników. Starano się zniszczyć legendę Piłsudskiego, którego nazywano burżuazyjnym nacjonalistą kontrrewolucji, potępiano najazd jaśniepanów polskich na Kraj Rad i powtarzano zgodnie z wykładnią komunistycznej propagandy z czasów II RP — że jaśniepańska Polska chciała zadusić Kraj Radziecki i przywrócić władzę obszarników i kapitalistów. Totalna ideologizacja życia społecznego w Polsce po II wojnie światowej objęła też edukację szkolną, a zwłaszcza naukę historii. We wszystkich opracowaniach historycznych z okresu PRL obraz wojny polsko-radzieckiej był kreślony zgodnie z celami ideologicznymi i propagandowymi wytycznymi kierownictwa PZPR, nad których realizacją czuwała cenzura (zob. Ronikier 2002).

W jednym z pierwszych podręczników historii, wydanym w 1948 roku, w rozdziale „Wojna z Rosją 1919-1920” krótko, bez emocji zrelacjonowano przebieg wojny (Historia Polski... 1948: 24-26). Jednak już w 1951 roku ukazuje się Historia Polski zatwierdzona przez Ministerstwo Oświaty, w której wojnę tę nazwano „interwencją antyradziecką", podkreślając, że „burżuazyjno-obszarniczy rząd polski rozpoczął zaborczą politykę skierowaną przeciwko Rosji Radzieckiej” i by odzyskać majątki i kapitał, „kapitaliści i obszarnicy rozpoczęli napastniczą wojnę zajmując Białoruś i Ukrainę" (Missalowa, Schönbrenner 1951: 240-242). Działania wojenne miały miejsce wbrew woli mas ludowych, a sama wojna to haniebna interwencja, która miała charakter grabieżczy. W podręczniku wydanym rok później (Historia Polski... 1952: 320-336) nasycenie słownictwem emocjonalnym wzrasta. Skierowany do uczniów propagandowy obraz wojny niezwykle negatywnie oceniał „antyradziecką i imperialistyczną politykę Piłsudskiego”. Pisano o „rozpętaniu hecy nacjonalistycznej”, o „kolonialnej eksploatacji ziem ukraińskich, białoruskich, litewskich i rosyjskich”, które znajdowały się „pod okupacją Polski”. Samą zaś wojnę określono jako „niesławną awanturę Piłsudskiego", którą zakończyło „grabieżcze włączenie do Polski niepolskich ziem ukraińskich i białoruskich" (Historia Polski... 1952: 336). $\mathrm{Z}$ tą „zdradziecką polityką imperializmu polskiego” walczyła KPP, a PPS głosiła hasła antyradzieckie i „szkalowała rewolucję rosyjską". Dopełnieniem tego negatyw- 
nego obrazu „imperialistycznej awantury wojennej” jest jednoznacznie pozytywna ocena działań rządu radzieckiego, który nie dążył do wojny i kierował się „szczerą wolą pokoju i porozumienia”. Chwalono też „zwycięski pochód Armii Czerwonej”, przed którą armia polska „bezładnie uciekała”, a Piłsudski „nie mając już siły do kontynuowania wojny i oczekując z trwogą kontrofensywy zmuszony był zawrzeć rozejm" (Historia Polski... 1952: 330).

Również w obszernej monografii z lat sześćdziesiątych XX wieku, poświęconej historii Polski, wyraźnie podkreślono, że „wojnę pomiędzy Polską a RSFRR zainicjowała Polska”, że Polska była „stroną atakującą i inicjatorem wojny” (Historia Polski 1966: 456). Była to „wojna klasowa”, „starcie dwóch ustrojów: kapitalistycznego i socjalistycznego”, „atak kontrrewolucji na rewolucję" (Historia Polski 1966: 457). Do wojny doprowadziła „ambicja przywódców i ciasny egoizm magnaterii kresowej” (Historia Polski 1966: 297). Polskiej „ekspansji na wschód” sprzeciwiali się polscy komuniści, którzy walczyli o przyjaźń między Polską a Rosją Radziecką” (Historia Polski 1966: 462). Autorzy monografii na pytanie, kto zwyciężył, odpowiadają: „Wygrana była bitwa warszawska, ale zwycięstwa w wojnie Polska nie uzyskała” i dodają: „Dla Polski bilans tej wojny był zdecydowanie ujemny” (Historia Polski 1966: 458).

Sposób opisu analizowanego konfliktu zbrojnego i jego aksjologizacja były podporządkowane ideologii i narracji narzuconej przez najważniejszego w czasach PRL sojusznika - ZSRR. Dlatego też w peerelowskim obrazie wojny polsko-radzieckiej w porównaniu z tym z II RP zupełnie zostały odwrócone role agresora i ofiary, zdyskredytowano też bohaterów, z Piłsudskim na czele, a cele i konsekwencje wojny zinterpretowano zgodnie $\mathrm{z}$ ideologią walki klasowej.

\section{3. „Pamięć przywrócona” o wojnie 1920 w III RP}

Po roku 1989 do polszczyzny oficjalnej powróciły usunięte w czasach PRL leksemy bolszewizm, bolszewik, sowiecki wraz z bagażem ich negatywnych konotacji. Na fali rozliczeń $z$ minionym ustrojem powrócono także do polonocentrycznej interpretacji wojny z roku 1920, nazywanej znowu - tak, jak w czasach II RP - polsko-sowiecka lub polsko-bolszewicka. W wydawanych już w III RP opracowaniach dziejów Polski historycy w różny sposób wyjaśniali przyczyny konfliktu zbrojnego z Rosja sowiecka. Swoją interpretację wojny z 1920 roku przedstawiają też historycy rosyjscy. Norman Davies tak podsumowuje ten spór: „Polscy historycy mówią o »napaści« bolszewików na Kresy, tak jakby należały one do Polski. Historycy sowieccy mówią o "polskich agresorach «, tak jakby Kresy należały do Rosji Sowieckiej. Oba stanowiska są bezpodstawne" (Davies 1997: 23).

Hanna Dylągowa, opisując konflikty związane z ustalaniem granic polski po I wojnie światowej, wyjaśnia koncepcję federacyjną Józefa Piłsudskiego i inkorporacyjną państwa narodowego Romana Dmowskiego. Pisząc o wojnie polsko-sowieckiej, autorka Historii Polski jednoznacznie stwierdza: „w lutym 1919 roku wojnę 
rozpoczęła Rosja sowiecka, zajmując tereny opuszczone przez armię niemiecką" (Dylągowa 2000: 131). Z kolei Jerzy Topolski w wielokrotnie wznawianej od 1992 roku Historii Polski, wyjaśniając przyczyny wojny, zwraca uwagę na „splot narodowych problemów”, na rozbudzenie świadomości narodowej oraz nacjonalizmów Ukraińców i Litwinów, a także na dążenie Piłsudskiego, „by Rosja Sowiecka znalazła się daleko od granic Polski” (Topolski 2015: 257-259). W opisie działań Armii Czerwonej na terenach zajętych znalazły się stwierdzenia o chęci ich aneksji i utworzenia republik sowieckich. Podobne rozwiązania - zdaniem autora - przygotowywano w Polsce „z udziałem polskich komunistów, którzy [...] opanowani ideą rewolucji weszli na drogę jawnej zdrady narodowej” (Topolski 2015: 261). Topolski podkreśla wagę zwycięstwa Polski w wojnie 1920 roku słowami: „Uratowało ono niepodległość Polski oraz obroniło Europę przed wojenną pożogą i zagrożeniem dla cywilizacji” oraz zauważa, że „bitwa warszawska (15 sierpnia) uznana została za jedną z najbardziej decydujących o biegu historii bitew świata” (Topolski 2015: 262).

W roku 1993 ukazał się podręcznik dla szkół średnich, we wstępie którego autorzy zaznaczają, że wybrali informacje podstawowe, „ale przy ich interpretacji i wyjaśnianiu staramy się wszędzie, gdzie można, ukazywać wieloznaczność pojęć, dyskusyjność ocen” (Radziwiłł, Roszkowski 1993: 5). W rozdziale pod tytułem „Walka o granice” uczniowie znajdą szczegółowy opis frontu wschodniego, informacje o polityce wschodniej Piłsudskiego i Dmowskiego, o stanowisku mocarstw Ententy w sprawie granic wschodnich. Podręcznik zawiera też wyrażone wprost oceny typu: gdziekolwiek bolszewicy ustanawiali władze, rozpoczynali rabunek i rewolucyjny terror; nad Polska zawisło śmiertelne niebezpieczeństwo; zaczęły działać trybunały rewolucyjne szerzace terror wśród ludności; obrona polski przed inwazja rosyjska; reżim bolszewicki na Ukrainie; Polska [...] mogła stać się łatwym łupem rewolucji bolszewickiej. Wróg to bolszewicy (najazd bolszewicki, atak bolszewicki, natarcie bolszewickie, ofensywa bolszewicka, bolszewicka Rosja) wspomagani na polskich terenach przez Tymczasowy Komitet Rewolucyjny Polski, który zapowiadał utworzenie polskiej republiki radzieckiej (Radziwiłł, Roszkowski 1993: 140-150).

Wiedzę o wojnie 1920 roku współcześnie młodzież czerpie również, a może przede wszystkim, z Internetu, w którym znaleźć można wiele specjalnie utworzonych stron, obrazów, filmów. W Wikipedii opis wojny polsko-bolszewickiej zajmuje 34 strony i kilkanaście odesłań do osobnych artykułów i linków zewnętrznych. Ogromne zainteresowanie wojną polsko-bolszewicką tłumaczyć należy między innymi chęcią „przywracania pamięci”, potrzebą podkreślania sławy polskiego oręża, a zwłaszcza dowartościowania i wzmacniania dumy narodowej po latach dominacji ZSRR i narzucanej przez to mocarstwo ideologicznej interpretacji naszej historii. Niezwykle uroczyście obchodzone są pod patronatem Prezydenta RP Andrzeja Dudy rocznice Bitwy Warszawskiej (pisanej wielkimi literami), nazywanej „Cudem nad Wisłą”. Z tej okazji odbywają się rekonstrukcje tej bitwy, półmaratony uliczne „Cud nad Wisłą”, Apele Poległych, uroczyste msze, modlitwy przy Krzyżu Pamięci ks. Ignacego Skorupki, odsłanianie pomników bohaterów wojny etc. Wszystkie te 
działania podnoszące rangę naszego zwycięstwa nad bolszewikami udokumentowane są w Internecie, a udział w nich polityków nadaje im charakter propagandowy.

W ostatnich latach kreowane obrazy wojny polsko-bolszewickiej nasycone są nową ideologią, realizowaną tym razem pod hasłem "powstawania z kolan”, wychowania społeczeństwa w duchu "prawdziwego patriotyzmu” i dumy z obrony chrześcijańskich wartości. Upowszechnianiu mitu bohaterskiego narodu i silnego państwa podporządkowane są kryteria oceny przeszłości i ustalanie hierarchii ważności minionych wydarzeń zgodnej z celami propagandowymi. Mitologizacji naszych dziejów, a zwłaszcza konfliktów zbrojnych, towarzyszy polonocentryzm i przekonanie, że my-naród zawsze staliśmy po stronie dobra, przeciwstawiając się niecnym dążeniom wroga. Ten wróg w wojnie $\mathrm{z}$ roku 1920 był w II RP i jest w III RP łączony ze stereotypem groźnego i okrutnego bolszewika, przed którym obroniliśmy całą chrześcijańską zachodnioeuropejską cywilizację. Jedynie w czasach PRL próbowano walczyć z mitem obrony przedmurza Chrześcijaństwa przez szerzenie ideologii o wojnie klasowej, o imperialistycznej awanturze wojennej jaśniepańskiej Polski.

\section{Bibliografia}

Davies N. (1997): Orzeł biały, czerwona gwiazda, przeł. A. Pawelec, Kraków.

Dąbrowska M. (1988): Dzienniki, t. 1, Warszawa.

Dąbski J. (1931): Pokój ryski, Warszawa.

Dylągowa H. (2000): Historia Polski 1795-1990, Lublin.

Garlicki A. (1989): Pierwsze lata Drugiej Rzeczypospolitej. Dzieje narodu i państwa polskiego, t. 3, Warszawa.

Historia Polski (1966): red. L. Grosfeld, H. Zieliński, t. 4, cz. 1 (1918-1926), rozdz. I-XIII (1918-1921), Warszawa.

Historia Polski i powszechna w krótkim zarysie (1948): oprac. A. Przyboś, z. 11, Toruń.

Historia Polski 1864-1945. Materiały do nauczania w klasie XI (1952): Warszawa.

Jarosz W. (1933): Opowiadania z dziejów powszechnych i polskich. Dla klas VI szkół powszechnych, cz. 2, Lwów.

Kamińska-Szmaj I. (1994): Judzi, zohydza, ze czci odziera. Język propagandy politycznej w prasie 19191923, Wrocław.

KPP w obronie niepodległości Polski (1952): Warszawa.

Kula M. (2004): Krótki raport o użytkowaniu historii, Warszawa.

Kwiatkowski P.T. (2008): Pamięć zbiorowa społeczeństwa polskiego w okresie transformacji, Warszawa. Missalowa G., Schönbrenner J. (1951): Historia Polski, Warszawa.

Pobóg-Malinowski W. (1956): Najnowsza historia polityczna Polski 1864-1945, t. 2, cz. 1, London.

Radziwiłł A., Roszkowski W. (1993): Historia 1871-1945, Warszawa.

Ronikier J. (2002): Mit i historia. Mitotwórcze funkcje podręczników szkolnych, Kraków.

Schönbrenner J. (1937): Obrazki z dziejów Polski. Podręcznik do nauki historii dla VI kl. szkół powszechnych drugiego stopnia. Kurs B, Warszawa.

Składanowski H. (2004): Stosunki polsko-sowieckie $w$ programach nauczania i podręcznikach historii w szkole powszechnej (podstawowej) w Polsce w latach 1932-1956, Toruń.

Szacka B. (2006): Czas przeszły - pamięć - mit, Warszawa.

Topolski J. (2015): Historia Polski, Poznań. 


\section{Controlling the collective memory. A multitude of propaganda voices on the Polish-Soviet War (1919-1921)}

\section{Summary}

The author of the article discusses the creation - in three successive historical periods - of the image of the 1919-1920 war between the Second Polish Republic and the Russian Soviet Federative Socialist Republic, referred to as the Polish-Soviet War, Polish-Bolshevik War, Polish-Russian War, 1920 War. The name, description and opinion about the war - in the Second Polish Republic, in the Polish People's Republic and in Poland today - depends on propaganda objectives, current politics and attitude to Poland's eastern neighbour. The image of the war of 1919-1921 is highly ideologised, as is evidenced by the choice of words and metaphors used to provoke emotions, to provide strong value judgements with regard to the enemy and thus to control society's behaviour as well as create myths and stereotypes which are kept in the collective memory for a long time. The history of this armed conflict has been and still is written under the pressure of various ideologies and propaganda strategies.

The aim of the article is to demonstrate that the image of wars in verbal accounts (history textbooks, historical monographs, literary works, oral histories etc.) and visual accounts (paintings, films etc.) depends on the historical context, socio-political determinants as well as the point of view of the individual creating the narrative of a given event. The shaping of collective memory is always accompanied by value judgements, selection of events and strong emotions.

Keywords: Polish-Soviet War, controlling collective memory, ideologisation of history. 